\title{
Accounting
}

\section{The impact of interest rate channel on the monetary transmission mechanism in Vietnam}

\author{
Thanh Tung Hoanga*, Van Anh Nguyen Thi ${ }^{a}$, Bich Vuong Nguyen Thi ${ }^{b}$ and Van Thoi Tran
}

${ }^{a}$ University of Labour and Social Affair, Vietnam

${ }^{b}$ Trung Vuong University, Vietnam

${ }^{c}$ Vietnam Trade Union University, Vietnam

\section{H R O N I C L E}

\section{Article history:}

Received March 22020

Received in revised format March

292020

Accepted April 82020

Available online

April 82020

Keywords:

Interest rate

Interest rate policy

Monetary transmission

mechanism

VECM model

Growth

Inflation

\section{A B S T R A C T}

In this article, the research team systematized the theoretical basis of the monetary transmission mechanism and the impact of interest rate channel in monetary transmission mechanism by Mishkin's approach and used the vector error correction model (VECM) to test the impact of interest rate channel in the monetary transmission mechanism in Vietnam in the period $2005-2019$. There were 8 endogenous variables included in the VECM model; namely Consumer price index (CPI); Gross domestic product (GDP) at constant 2010 prices (GDPR); Money supply (M2); Refinancing interest rate (ISBV); Average lending interest rate in VND (ILR); Bilateral real exchange rate (ER); Credit to the economy (CRE); VN-Index (VN-INDEX); and, 2 exogenous variables: world consumer price index (PW) and US Federal Reserve interest rate (IFED). The results have shown that: money supply had a clearer effect on average lending interest rate than refinancing rate; Interest rate channel was an important channel to transfer the impact of monetary policy on inflation; Exchange rate and interest rates channel influenced economic growth in Vietnam more strongly than credit and financial asset prices channel did. Besides, the model results also confirm that in Vietnam, inflation in the past played an important role in determining current inflation.

\section{The impact of interest rate channel in the monetary transmission mechanism}

\subsection{Monetary transmission mechanism}

Keynes (1936) showed the monetary transmission mechanism based on the analysis of the process of the impact of monetary policy on interest rates and the effects of interest rates, the marginal profit of investment on spending for investment. Keynes has pointed out to the monetary transmission mechanism according to the following Fig. 1.



Fig. 1. The monetary transmission mechanism to economic of Keynes

* Corresponding author

E-mail address: hoangthanhtung15@gmail.com (T. T. Hoang) 
According to Mankiw (2009), the mechanism of monetary transmission affects the economy through three channels: asset prices (bonds, stocks), interest rates, exchange rates. The monetary transmission mechanism of Mankiw is generalized by Fig. 2 as follows:

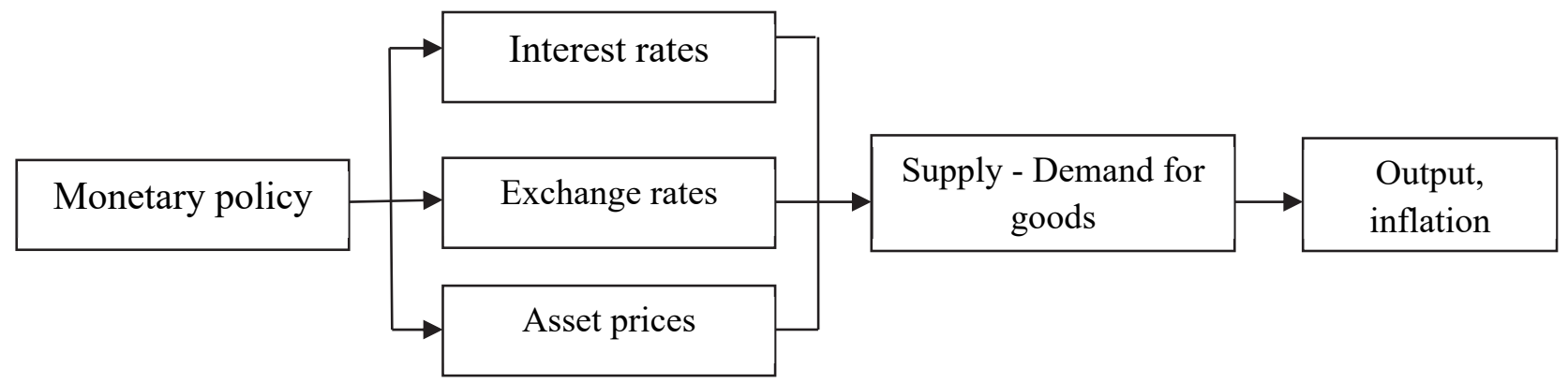

Fig. 2. The monetary transmission mechanism to economic of Mankiw

Source: Mankiw (2009)

According to Mishkin (2010), the monetary transmission mechanism describes the process from the changes in a monetary policy specific, the changes in the amount of money in circulation (or nominal short-term interest rates) affects variables through transmission channels such as interest rate channel, exchange rate channel, asset price channel, credit channel, cash flow channel as shown in Fig. 3 as follows



Fig. 3. The monetary transmission mechanism to economic of Mishkin

The concepts mentioned by researchers have one thing in common: Monetary transmission mechanism is the process by which the changes in monetary policy are transformed into changes in output and prices in the economy.

The monetary transmission mechanism is a process where the changes in monetary policy lead to a series of other changes in economic variables such as interest rates, asset prices, consumer spending, and exchange rate, cash flow, supply creditability of the commercial banking system, etc. (Hoang \& Thi, 2020; Hoang et al., 2020; Hung \& Pfau, 2009; Nguyen \& Nguyen, 2010). With the money transmission channels mentioned by the researchers, Mishkin's approach can be said to mention the most complete transmission channels. Interest rate channel following Mishkin's approach not only included traditional interest rate channel like Keynes's but also explains through exchange rate and credit channel. Therefore, when studying the impact of the interest rate channel in the monetary transmission mechanism, the research team uses the approach by Mishkin's theory as Fig.3. 


\subsubsection{Impact through the traditional interest rate channel}

The effect of monetary policy adjustment is firstly transmitted through the traditional interest rate channel and described by Keynes in the following figure:

$$
\text { Extensive monetary policy } \rightarrow \mathrm{r} \downarrow \rightarrow \mathrm{I} \uparrow \rightarrow \mathrm{Y} \uparrow
$$

With other factors constant, the expansionary monetary policy makes real interest rates decrease $(r \downarrow)$ leading to reduce investment costs, stimulate investment rising (I $\uparrow$ ); which increases aggregate demand and ultimately rising output $(\mathrm{Y} \uparrow)$. The effectiveness of extensive monetary policy depends on the organizational characteristics of financial markets and the level of market expectations. It should be noted that only when the real interest rate (r) changes, does it affect investment (I)? When the central bank implements extensive monetary policy, nominal interest rates decrease (i $\downarrow$ ), while commodity prices have not changed, causing real interest rates to fall $(\mathrm{r} \downarrow)$. Investment demand is sensitive to real interest rates rather than nominal interest rates, it is this perception that changes the sequence of the effect of the volume of money on output as follows:

$$
\text { Extensive monetary policy } \rightarrow \mathrm{P} \uparrow \uparrow \rightarrow \pi^{\mathrm{e}} \uparrow \rightarrow \mathrm{r} \downarrow \rightarrow \mathrm{I} \uparrow \rightarrow \mathrm{Y} \uparrow
$$

The monetary policy extensive firstly reduces the nominal interest rate immediately, while the price level and inflation only increase slowly in the long term. Monetary policy extensive impacts on expected price (Pe) and expected inflation (e), leading

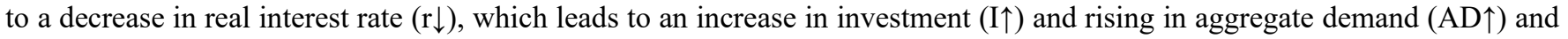
making an increase in output product $(\mathrm{Y} \uparrow)$.

\subsubsection{Impact of interest rates through exchange rates channel}

With the other factors remain unchanged, when the Central Bank enforces the extensive monetary policy, real interest rates will decrease; the domestic currency becames less attractive than foreign currencies, leading to an increase in foreign exchange demand and exchange rate $(\mathrm{E} \uparrow)$, which is a contributor to an increase in exports and import restrictions, resulting in an increase in net exports (NX $\uparrow)$ and rising in total output product $(\mathrm{Y} \uparrow)$.

$$
\text { Extensive monetary policy } \rightarrow \mathrm{r} \downarrow \rightarrow \mathrm{E} \uparrow \rightarrow \mathrm{NX} \uparrow \rightarrow \mathrm{Y} \uparrow
$$

Studies have shown that the exchange rate channel plays an important role in the channel of monetary transmission to the economy. The exchange rate transmission channel includes the affected mechanism of the interest rate. In case the interest rate of the local currency decreases against the foreign currency, the value of the local currency deposit is lower than the value of the foreign currency deposit. Therefore, the local currency tends to depreciate against foreign currency. The devaluation of the domestic currency will stimulate exports and leading to a rising in output.

\subsubsection{Impact of interest rates through the credit channel}

The dissatisfaction with the explanation of the impact of interest rate on the spending for long-term assets under the traditional interest rate channel leads to a new explanation of the monetary transmission mechanism of the interest rate channel via credit channel. Credit channel includes Balance of payment channel; Credit ability channel; Cash flow channel; Channel price fluctuations; Liquidity channel. To examine the impact of interest rate via credit channel, the research team focused on the Cash flow channel based on the problem of asymmetric information in the financial market; and the Liquidity channel based on the relationship between interest rates and cash flows. A credit channel is also a transmission channel that includes the affected mechanism of the interest rate.

\section{- Affect adverse selection and moral risks}

The extensive monetary policy reduces nominal interest rates ( $i \downarrow$ ), leads to cost reduction for businesses, thereby increasing cash flow and increasing solvency of enterprises. Enterprises can access bank credit more easily. High liquidity will reduce adverse selection and moral risks, the bank can lend more, investment (I $\uparrow$ ) and total output will increase (Y $\uparrow)$

\section{- Affect the liquidity of the household}

Extensive monetary policy $\rightarrow \mathrm{i} \downarrow \rightarrow$ cash flow $\uparrow \rightarrow$ adverse selection and moral risks $\downarrow$

$$
\rightarrow \text { credit } \uparrow \rightarrow \mathrm{I} \uparrow \rightarrow \mathrm{Y} \uparrow
$$

The effect of interest rates on credit channels to the liquidity of households is explained by the increase in money supply, which reduces interest rates $(\mathrm{i} \downarrow)$, thereby growing cash flows for consumption and spending on durable goods and real estate, increase in aggregate demand and total output $(\mathrm{Y} \uparrow)$. 
Extensive monetary policy $\rightarrow \mathrm{i} \downarrow \rightarrow$ cash flows for consumption $\uparrow \rightarrow$ financial difficulties $\downarrow$ $\rightarrow$ spending on durable goods and real estate $\uparrow \rightarrow \mathrm{Y} \uparrow$

\section{Applying the VECM model to analyze the impact of the interest rate channel in the monetary transmission mechanism in Vietnam}

\subsection{VECM model and variables in the model}

\subsubsection{VECM model}

To examine the impact of interest rate channel in the monetary transmission mechanism in Vietnam, the research team used the vector error correction model (VECM). VECM model is used to consider the effect and interdependence between some macroeconomic variables over time. In the VECM model, the variables have the same role. The VECM model is useful for researchers who want to consider the response of one variable to the shock of one or more other variables in the economy. So the research team selected the VECM model to consider the impact of interest rate channel in the monetary transmission mechanism in Vietnam from 2005 to 2019. In the VECM model, suppose that Yt is a vector of nonstop variables (economic variables), considering the VAR model (p) without defined components

$$
\mathrm{Y}_{t}=\mathrm{A}_{1} \mathrm{Y}_{t-1}+\mathrm{A}_{2} \mathrm{Y}_{t-2}+\cdots+\mathrm{A}_{p} \mathrm{Y}_{t-p}+\mathrm{u}_{t}
$$

Rewrite this model as follows

$$
\begin{gathered}
\mathrm{Y}_{t}-\mathrm{Y}_{t-1}=\left(\mathrm{A}_{1}+\mathrm{A}_{2}+\cdots+\mathrm{A}_{p}-\mathrm{I}\right) \mathrm{Y}_{t-1}-\left(\mathrm{A}_{2}+\cdots+\mathrm{A}_{p}\right)\left(\mathrm{Y}_{t-1}-\mathrm{Y}_{t-2}\right)-\left(\mathrm{A}_{3}+\cdots+\mathrm{A}_{p}\right)\left(\mathrm{Y}_{t-2}-\mathrm{Y}_{t-3}\right)-\cdots-\mathrm{A}_{p}\left(\mathrm{Y}_{t-p+1}\right. \\
\left.\quad-\mathrm{Y}_{t-p}\right)+\mathrm{u}_{t} \\
\begin{array}{c}
D \mathrm{Y}_{t}=\Pi \mathrm{Y}_{t-1}+C_{1} D \mathrm{Y}_{t-1}+C_{2} D \mathrm{Y}_{t-2}+\cdots+C_{p-1} D \mathrm{Y}_{t-p+1}+\mathrm{u}_{t}
\end{array}
\end{gathered}
$$

Therein: $\Pi=A_{1}+A_{2}+\cdots+A_{p}-I ; C_{i}=-\sum_{j=i+1}^{p} A_{j} ; i=1,2, \ldots, p-1$

Move the terms $C_{i} D \mathrm{Y}_{t-i}$ of the model (2) to the left side:

$$
D Y_{t}-C_{1} D Y_{t-1}-C_{2} D Y_{t-2}-\cdots-C_{p-1} D Y_{t-p+1}=\Pi Y_{t-1}+u_{t}
$$

Put $C(L)=1-C_{1} L-C_{2} L^{2}-\cdots-C_{p-1} L^{p-1} ; \mathrm{d}(\mathrm{L})=1+\theta_{1} \mathrm{~L}+\theta_{2} \mathrm{~L}^{2}+\cdots$

Thus

$$
C(L) D \mathrm{Y}_{t}=\Pi \mathrm{Y}_{t-1}+\mathrm{d}(\mathrm{L}) \mathrm{u}_{t}
$$

Model (3) is called the vector error correction model (VECM) with the term $\Pi Y_{t-1}$ is the error correction part.

\subsubsection{Variables in the model}

Based on the transmission mechanism of the impact of interest rate channel following the Mishkin's approach, the research team identified variables in the VECM model including 8 endogenous variables. Consumer price index (CPI); GDP at constant 2010 prices (GDPR); Money supply - Total means of payment (M2); Refinancing interest rate (ISBV); Average lending interest rate in Vietnamese Dong (ILR); Bilateral real exchange rate (ER); Credit of the economy (CRE); Vietnamese index (VNINDEX). Besides, the research team added to the model 2 exogenous variables: The world consumer price index (PW) and the US Federal Reserve interest rate (IFED). In Table1, the consumer price index (CPI) variable represents the inflation index; the gross domestic product at constant 2010 prices (GDPR) represents the income or output production of the economy. At the same time, the GDPR variable has been seasonally adjusted by the moving average method, to ensure the shocks reflecting changes in the long-term trend of that variable. The GDPR variable after adjustment is denoted as GDP. The money supply variable (M2) and the refinancing interest rate (ISBV) represent monetary policy. The average variable interest rates of VND loans (ILR), the Bilateral real exchange rate (ER), the credit to the economy (CRE), Vietnamese Index (VN INDEX) represent the transmission channels of monetary policy. Bilateral real exchange rate (ER) is calculated from the bilateral nominal exchange rate data were 
synthesized from IFS and GSO by the research team. $E R=\frac{E \cdot P_{W}}{C P I}$, with $\mathrm{E}$ is the nominal exchange rate of VND / USD, PW is the world consumer price index and CPI is the consumer price index of Vietnam.

Table 1

Variables in the VECM model

\begin{tabular}{|c|c|c|c|c|}
\hline STT & Symbol & & Variables & Data Source \\
\hline 1 & CPI & \multirow{4}{*}{$\begin{array}{l}\text { Target variable } \\
\text { The represents } \\
\text { monetary policy } \\
\text { variable }\end{array}$} & Consumer price index & TCTK, IFS \\
\hline 2 & $\mathrm{GDP}_{\mathrm{R}}$ & & GDP at constant 2010 prices & TCTK \\
\hline 3 & M2 & & Money supply - Total means of payment & IFS, NHNN \\
\hline 7 & ISBV & & Refinancing interest rate & IFS, NHNN \\
\hline 4 & ILR & \multirow{4}{*}{$\begin{array}{l}\text { Representing the } \\
\text { monetary policy } \\
\text { transmission channel }\end{array}$} & The average lending interest rate in Vietnamese dong & IFS, NHNN \\
\hline 5 & ER & & Bilateral real exchange rate & IFS, NHNN \\
\hline 6 & CRE & & The credit of the economy & NHNN \\
\hline 8 & VN-INDEX & & Vietnamese Index & HOSE \\
\hline 9 & PW & \multirow{2}{*}{ Exogenous variables } & The world consumer price index & IFS \\
\hline 10 & IFED & & US Federal Reserve interest rate & IFS \\
\hline
\end{tabular}

Source: Synthetic of the research team

The average VN-Index variable by quarter is calculated by calculating the average VN-Index of the months in the quarter. The average VN-Index of each month is determined by getting the index of the first trading day of the month and the index of the last trading day of the month, taking the average. VN-Index data is updated on https://www.stockbiz.vn/IndicesStats.aspx

Table 2

Descriptive statistics the data of variables used in the model

\begin{tabular}{lccccccc}
\hline & Mean & Median & Maximum & Minimum & Sum & Sum Sq. Dev. & Observations \\
\hline CPI & 121.8184 & 133.01 & 169.1 & 61.35 & 6943.65 & 66593.35 & 57 \\
GDP & 621684.7 & 603194.5 & 934636.5 & 397161.5 & 35436030 & $1.31 \mathrm{E}+12$ & 57 \\
M2 & 4369184 & 3702867 & 10573725 & 690404 & $2.49 \mathrm{E}+08$ & $4.75 \mathrm{E}+14$ & 57 \\
ISBV & 7.797368 & 6.5 & 15 & 5 & 444.45 & 404.4621 & 57 \\
IR & 2.84 & 3.8 & 7.8 & -7.9 & 161.88 & 714.8504 & 57 \\
ER & 18739.15 & 18484.06 & 21772.35 & 17205.92 & 1068131 & 84900873 & 57 \\
CRE & 3475246 & 3081745 & 8195393 & 516667 & $1.98 \mathrm{E}+08$ & $2.79 \mathrm{E}+14$ & 57 \\
VN-INDEX & 621.7793 & 561.19 & 1102.93 & 281.36 & 35441.42 & 2844229 & 57 \\
PW & 111.8302 & 111.11 & 144.32 & 83.97 & 6374.32 & 17749.41 & 57 \\
IFED & 1.348246 & 0.13 & 5.25 & 0.13 & 76.85 & 168.9778 & 57 \\
\hline
\end{tabular}

The following variables GDP, CPI, M2, ISBV, ILR, ER, CRE, VNINDEX, PW, IFED after being log as LGDP, LCPI, LM2, LISBV, LILR, LER, LCRE, LVNINDEX, LPW, LIFED and lognormal variants of log data series, are denoted as DLGDP, DLCPI, DLM2, DLISBV, DLILR, DLER, DLCRE, DLVNINDEX, DLPW, DLIFED. With such a model structure, the research team examined the impact of money supply and refinancing interest rates on the average loan interest rate of Vietnamese Dong (VND) following by considering the impact of the average VND loan interest rate on the remaining endogenous variables in the model. At the same time, we consider the reaction of inflation and economic growth to the shock of other endogenous variables, thereby considering the effect of the interest rate channel on the two target variables.

\subsection{Checking the stability of the data series}

Before proceeding specific analysis steps, the research team conducted the stability test of the data series (including 60 observations, quarterly data, from the first quarter of 2005 to the fourth quarter of 2019, however, since the GDP variable has been seasonally adjusted by running average method, the number of observations is 57 observations).

\subsubsection{Determine the stopping behavior of the variables included in the model}

To test the stopping behavior of the variables after the logarithmization, the research team performed Augmented Dickey Fuller test (ADF test), the results are shown in Table 3. From the results at Table 3, we can see the chains LGDP, LCPI, LM2, LISBV, LILR, LER, LCRE, LVN-INDEX, LPW, LIFED are non-stop at the significant levels of $1 \%, 5 \%$ and $10 \%$. However, all their differential at first level are stop chain at significance levels of $1 \%, 5 \%$ and $10 \%$. This suggests that the use of the VECM model to analyze the long-term relationship between these chains is appropriate. 
Table 3

Determine the stopping behavior of the variables by ADF test

\begin{tabular}{|c|c|c|c|c|}
\hline \multirow{2}{*}{ Variable } & \multirow{2}{*}{ ADF } & \multicolumn{3}{|c|}{ Test critical values: } \\
\hline & & $1 \%$ level & $5 \%$ level & $10 \%$ level \\
\hline LGDP & -1.536324 & -4.130526 & -3.492149 & -3.174802 \\
\hline DLGDP & -8.907017 & -3.555023 & -2.915522 & -2.595565 \\
\hline LCPI & -0.289342 & -4.121303 & -3.487845 & -3.172314 \\
\hline DLCPI & -5.357294 & -3.548208 & -2.912631 & -2.594027 \\
\hline LM2 & -1.726625 & -4.121303 & -3.487845 & -3.172314 \\
\hline DLM2 & -5.341664 & -3.548208 & -2.912631 & -2.594027 \\
\hline LISBV & -2.027083 & -4.121303 & -3.487845 & -3.172314 \\
\hline DLISBV & -5.14886 & -3.548208 & -2.912631 & -2.594027 \\
\hline LILR & -2.006556 & -4.121303 & -3.487845 & -3.172314 \\
\hline DLILR & -4.936510 & -3.548208 & -2.912631 & -2.594027 \\
\hline LER & -1.165409 & -4.121303 & -3.487845 & -3.172314 \\
\hline DLER & -5.254197 & -3.548208 & -2.912631 & -2.594027 \\
\hline LCRE & -1.437926 & -4.121303 & -3.487845 & -3.172314 \\
\hline DLCRE & -7.474043 & -3.548208 & -2.912631 & -2.594027 \\
\hline LVN-INDEX & -2.191514 & -4.121303 & -3.487845 & -3.172314 \\
\hline DLVN-INDEX & -5.961158 & -3.548208 & -2.912631 & -2.594027 \\
\hline LPW & -2.641373 & -4.121303 & -3.487845 & -3.172314 \\
\hline DLPW & -6.060006 & -3.548208 & -2.912631 & -2.594027 \\
\hline LIFED & -0.854722 & -4.121303 & -3.487845 & -3.172314 \\
\hline DLIFED & -7.045203 & -3.548208 & -2.912631 & -2.594027 \\
\hline
\end{tabular}

\subsubsection{Determine optimal latency}

In order to obtain accurate results from the VECM model, beside considering stopping behavior of the variables, the research team determined the optimal latency of the model. According to the statistical standards LR, FPE, AIC, HQ the model has an optimal latency of 3 (Table 4).

\section{Table 4}

Determine optimal latency of the model

\begin{tabular}{|c|c|c|c|c|c|c|}
\hline Lag & $\log L$ & LR & FPE & AIC & $\mathrm{SC}$ & HQ \\
\hline 0 & 711.1329 & $\mathrm{NA}$ & $1.22 \mathrm{e}-21$ & -25.44937 & -24.56537 & -25.10845 \\
\hline 1 & 1044.922 & 531.5898 & $5.86 \mathrm{e}-26$ & -35.44155 & $-32.20024 *$ & -34.19151 \\
\hline 2 & 1153.985 & 141.3784 & $1.36 \mathrm{e}-26$ & -37.11056 & -31.51194 & -34.95139 \\
\hline 3 & 1258.172 & $104.1870^{*}$ & $5.24 \mathrm{e}-27^{*}$ & $-38.59897 *$ & -30.64303 & $-35.53068^{*}$ \\
\hline
\end{tabular}

Endogenous variables: LGDP LCPI LCRE LVNINDEX LER LILR LISBV LM2

Exogenous variables: C LPW LIFED

\subsubsection{Granger causality test, verify cointegrated relationships between chains, chain correlation test and residual normality} tests

\section{a. Granger causality test}

According to the results of Granger causality test, with a 5\% significance level, we can confirm 32 relationship: (1) CPI has a causal relationship with CRE; (2) CPI has a causal relationship with GDP; (3) IFED has a causal relationship with CPI and vice versa; (4) CPI has a causal relationship with ILR; (5) ISBV has a causal relationship with CPI and vice versa; (6) CPI has a causal relationship with M2; (7) VN-INDEX has a causal relationship with CPI and vice versa; (8) ER has a causal relationship with CRE; (9) CRE has a causal relationship with GDP; (10) CRE has a causal relationship with ILR; (11) CRE has a causal relationship with ISBV; (12) M2 has a causal relationship with CRE and vice versa; (13) ER has a causal relationship with GDP; (14) IFED has a fruitful relationship with ER and vice versa; (15) ER has a causal relationship with ILR; (16) ISBV has a causal relationship with ER; (17) ER has a causal relationship with M2; (18) ER has a causal relationship with VN-INDEX; (19) IFED has a causal relationship with GDP; (20) ILR has a causal relationship with GDP; (20) ILR has a causal relationship with GDP; (21) ISBV has a causal relationship with GDP and vice versa; (22) VNINDEX has a causal relationship with GDP; (23) ILR has a causal relationship with IFED; (24) ISBV has a causal relationship with IFED; (25) VNINDEX has a causal relationship with IFED; (26) ISBV has a causal relationship with ILR; (27) M2 has a causal relationship with ILR; (28) PW has a causal relationship with ILR; (29) VN-INDEX has a causal relationship with ILR and vice versa; (30) ISBV has a causal relationship with VN-INDEX; (31) M2 has a causal relationship with PW; (32) PW has a causal relationship with VN-INDEX. With a 10\% significance level, it can be further confirmed: (1) CRE has a causal relationship with the CPI; (2) M2 has a causal relationship with the CPI; (3) ILR has a causal relationship with CRE; (4) ISBV has a causal relationship with CRE; (5) CRE has a causal relationship with PW; (6) ER has a causal relationship with PW; (7) M2 has a causal relationship with GDP; (8) M2 has a causal relationship with IFED; (9) PW has a causal relationship with IFED; (10) M2 has a causal relationship with ISBV and vice 
versa; (11) ISBV has a causal relationship with PW; (12) VN INDEX has a causal relationship with ISBV; (13) PW has a causal relationship with M2; (14) VN INDEX has a causal relationship with PW.

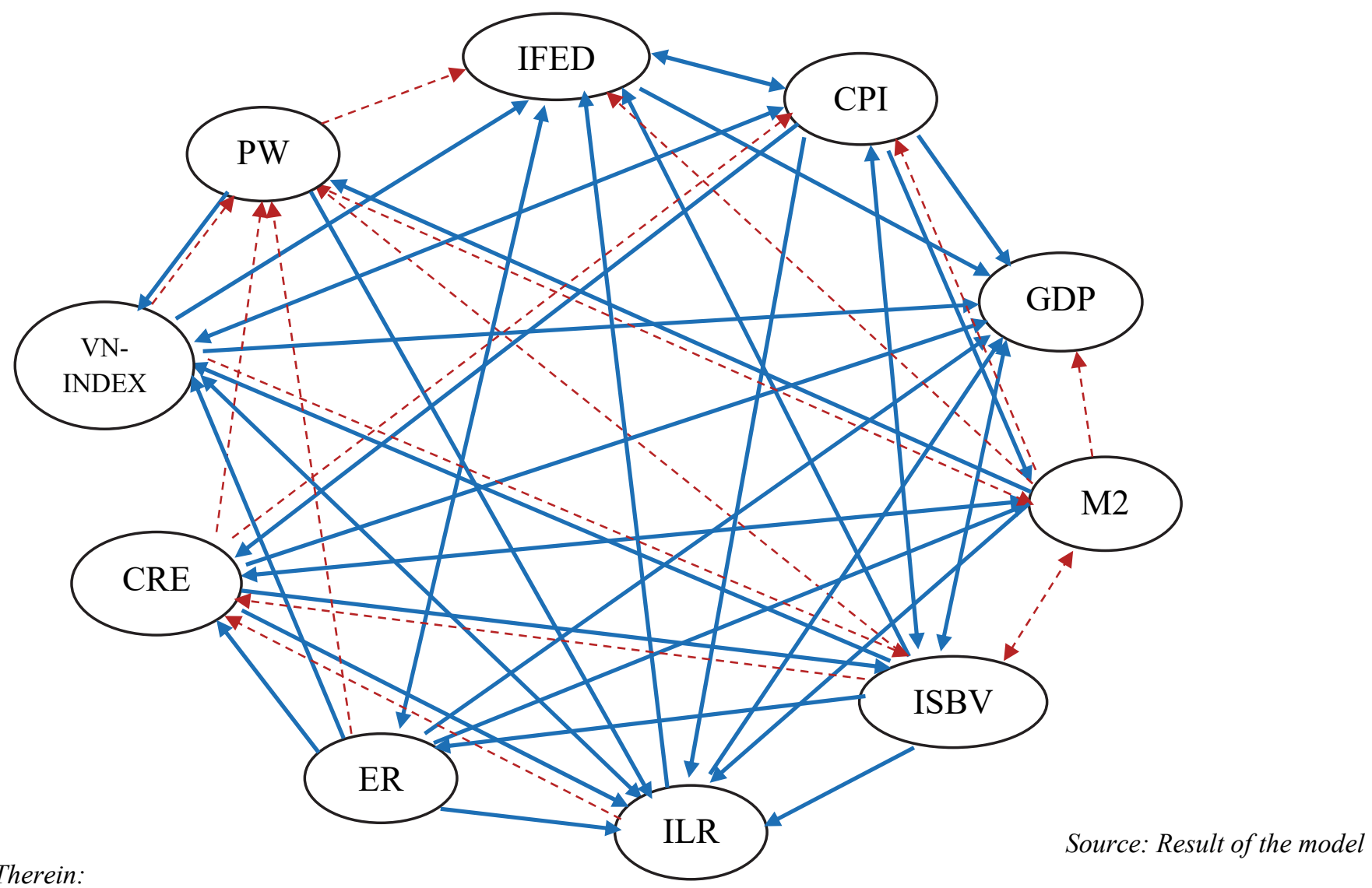

Therein:

Line of a causal relationship with a significance level of $5 \%$

$\rightarrow$ Line of a causal relationship with a significance level of $10 \%$

Fig. 4. Describe the causal relationship between variables

\section{b. Cointegrated relationships test}

Table 5

Verify cointegrated relationships between chains (Unrestricted Cointegration Rank Test (Trace))

\begin{tabular}{|c|c|c|c|c|}
\hline Hypothesized No. of CE(s) & Eigenvalue & Trace Statistic & Critical Value 0.05 & Prob.** \\
\hline None $*$ & 0.931142 & 492.3522 & 159.5297 & 0.0000 \\
\hline At most $1 *$ & 0.911165 & 350.5400 & 125.6154 & 0.0000 \\
\hline At most $2 *$ & 0.842527 & 222.2281 & 95.75366 & 0.0000 \\
\hline At most $3 *$ & 0.666986 & 124.2576 & 69.81889 & 0.0000 \\
\hline At most $4 *$ & 0.513656 & 65.98032 & 47.85613 & 0.0004 \\
\hline At most 5 & 0.315390 & 27.77588 & 29.79707 & 0.0840 \\
\hline At most 6 & 0.132760 & 7.693854 & 15.49471 & 0.4987 \\
\hline At most 7 & 0.002724 & 0.144550 & 3.841466 & 0.7038 \\
\hline
\end{tabular}

Series: LGDP LCPI LCRE LVN-INDEX LER LILR LISBV LM2 Exogenous series: LIFED LPW

Unrestricted Cointegration Rank Test (Maximum Eigenvalue)

\begin{tabular}{|c|c|c|c|c|}
\hline Hypothesized No. of CE(s) & Eigenvalue & Trace Statistic & Critical Value 0.05 & Prob.** \\
\hline None $*$ & 0.931142 & 141.8122 & 52.36261 & 0.0000 \\
\hline At most $1 *$ & 0.911165 & 128.3118 & 46.23142 & 0.0000 \\
\hline At most $2 *$ & 0.842527 & 97.97054 & 40.07757 & 0.0000 \\
\hline At most $3 *$ & 0.666986 & 58.27728 & 33.87687 & 0.0000 \\
\hline At most $4 *$ & 0.513656 & 38.20444 & 27.58434 & 0.0015 \\
\hline At most 5 & 0.315390 & 20.08203 & 21.13162 & 0.0696 \\
\hline At most 6 & 0.132760 & 7.549305 & 14.26460 & 0.4264 \\
\hline At most 7 & 0.002724 & 0.144550 & 3.841466 & 0.7038 \\
\hline
\end{tabular}

* denotes rejection of the hypothesis at the 0.05 level

**MacKinnon-Haug-Michelis (1999) p-values 
According to the cointegration test, there are 5 co-integration relationships between chains. The results of the Maximum Eigenvalue test also show that there are 5 co-integration relationships between chains at the significance level of 5\%. We choose the number of cointegrating relationships between the series of 5 at this significant level.

\section{c. Chained correlation}

Test results (Table 6) have shown that the model does not suffer from the chain self-correlation phenomenon at the $1 \%$ significance level.

\section{Table 6}

Chained correlation test

\begin{tabular}{|c|c|c|}
\hline Lags & LM-Stat & Prob \\
\hline 1 & 91.29142 & 0.0142 \\
\hline 2 & 83.74977 & 0.0494 \\
\hline 3 & 72.74757 & 0.2122 \\
\hline 4 & 85.31448 & 0.0387 \\
\hline 5 & 80.71965 & 0.0773 \\
\hline 6 & 59.24176 & 0.6451 \\
\hline 7 & 67.52170 & 0.3578 \\
\hline 8 & 72.16750 & 0.2261 \\
\hline 9 & 62.01151 & 0.5472 \\
\hline 10 & 55.41053 & 0.7693 \\
\hline 11 & 50.75753 & 0.8854 \\
\hline 12 & 56.02089 & 0.7509 \\
\hline
\end{tabular}

\section{d. Residual Normality Tests}

Source: Result of the model

With a 5\% significance level, the standard distribution residual described in Table 7

\section{Table 7}

VEC Residual Normality Tests

\begin{tabular}{|c|c|c|c|c|}
\hline Component & Skewness & Chi-sq & df & Prob. \\
\hline 1 & 0.054606 & 0.026339 & 1 & 0.8711 \\
\hline 2 & 0.046642 & 0.019216 & 1 & 0.8897 \\
\hline 3 & -0.087516 & 0.067655 & 1 & 0.7948 \\
\hline 4 & -0.007101 & 0.000445 & 1 & 0.9832 \\
\hline 5 & 0.090668 & 0.072616 & 1 & 0.7876 \\
\hline 6 & 0.236340 & 0.493398 & 1 & 0.4824 \\
\hline 7 & 0.004458 & 0.000176 & 1 & 0.9894 \\
\hline 8 & 0.178481 & 0.281390 & 1 & 0.5958 \\
\hline Joint & & 0.961236 & 8 & 0.9985 \\
\hline Component & Kurtosis & Chi-sq & df & Prob. \\
\hline 1 & 3.602109 & 0.800599 & 1 & 0.3709 \\
\hline 2 & 2.839729 & 0.056725 & 1 & 0.8117 \\
\hline 3 & 2.515050 & 0.519348 & 1 & 0.4711 \\
\hline 4 & 3.102211 & 0.023071 & 1 & 0.8793 \\
\hline 5 & 2.241684 & 1.269886 & 1 & 0.2598 \\
\hline 6 & 4.229213 & 3.336712 & 1 & 0.0677 \\
\hline 7 & 3.068304 & 0.010303 & 1 & 0.9192 \\
\hline 8 & 4.134512 & 2.842386 & 1 & 0.0918 \\
\hline
\end{tabular}

\begin{tabular}{lccc}
\hline Component & Jarque-Bera & df & Prob. \\
\hline 1 & 0.826938 & 2 & 0.6614 \\
2 & 0.075942 & 2 & 0.9627 \\
3 & 0.587003 & 2 & 0.7456 \\
4 & 0.023516 & 2 & 0.9883 \\
5 & 1.342501 & 2 & 0.5111 \\
6 & 3.830110 & 2 & 0.1473 \\
7 & 0.010478 & 2 & 0.9948 \\
8 & 3.123776 & 2 & 0.2097 \\
\hline Joint & 9.820266 & 16 & 0.8758 \\
\hline
\end{tabular}




\subsubsection{Estimated results}

After checking the stopping behavior, determining the optimal latency, Granger causality, cointegration relationships, chain correlation, and residual normality, the authors estimated the model (Table 8).

\section{Table 8}

Estimated results of VECM model

\begin{tabular}{|c|c|c|c|c|c|c|c|c|}
\hline Cointegrating Eq: & CointEq1 & CointEq2 & CointEq3 & CointEq4 & CointEq5 & & & \\
\hline LGDP (-1) & 1.000000 & 0.000000 & 0.000000 & 0.000000 & 0.000000 & & & \\
\hline LCPI (-1) & 0.000000 & 1.000000 & 0.000000 & 0.000000 & 0.000000 & & & \\
\hline $\operatorname{LCRE}(-1)$ & 0.000000 & 0.000000 & 1.000000 & 0.000000 & 0.000000 & & & \\
\hline LVN-INDEX (-1) & 0.000000 & 0.000000 & 0.000000 & 1.000000 & 0.000000 & & & \\
\hline $\operatorname{LER}(-1)$ & 0.000000 & 0.000000 & 0.000000 & 0.000000 & 1.000000 & & & \\
\hline LILR (-1) & -0.075025 & -0.036633 & -0.078240 & -0.772191 & -0.015508 & & & \\
\hline $\operatorname{LISBV}(-1)$ & -0.027454 & 0.100975 & -0.192273 & 0.855739 & -0.231420 & & & \\
\hline $\operatorname{LM} 2(-1)$ & 0.251838 & -1.161520 & -0.967575 & 1.202532 & 0.619469 & & & \\
\hline $\mathrm{C}$ & -16.89640 & 12.62124 & 0.296759 & -24.48997 & -18.66812 & & & \\
\hline Error Correction: & $\mathrm{D}$ (LGDP) & $\mathrm{D}(\mathrm{LCPI})$ & D(LCRE) & D(LVNINDEX) & $\mathrm{D}(\mathrm{LER})$ & D(LILR) & D(LISBV) & D(LM2) \\
\hline CointEq1 & -0.120213 & -1.669145 & -0.434969 & 3.763606 & 1.312654 & -1.323746 & -5.897601 & 0.794957 \\
\hline CointEq2 & -0.044675 & -0.819555 & -0.453916 & -0.666954 & 0.458688 & -0.933662 & -2.097689 & 0.474864 \\
\hline CointEq3 & 0.081305 & -0.650189 & -0.893634 & 0.055263 & 0.699317 & 1.386001 & 2.404277 & 0.150364 \\
\hline CointEq4 & 0.003722 & -0.042485 & 0.001445 & -0.708130 & 0.007507 & 0.097629 & -0.056398 & 0.039009 \\
\hline CointEq5 & 0.033433 & 0.128032 & 0.534484 & -1.900262 & -0.358378 & 0.014788 & 2.423421 & 0.255433 \\
\hline D(LGDP(-1)) & -0.580399 & 0.901065 & 1.974678 & 1.924858 & -1.069656 & -0.761204 & 0.022682 & -0.331055 \\
\hline $\mathrm{D}(\operatorname{LGDP}(-2))$ & -0.750750 & 0.834093 & -1.720733 & 1.885253 & -0.564748 & -3.392815 & 2.178222 & -1.167483 \\
\hline D(LGDP(-3)) & -0.388844 & 0.485762 & 0.487408 & 5.642482 & -0.832974 & -0.579510 & -2.471732 & -0.259989 \\
\hline $\mathrm{D}(\operatorname{LCPI}(-1))$ & -0.079865 & -0.057135 & -0.164325 & -3.433733 & -0.040937 & 1.048477 & 1.850349 & -0.440692 \\
\hline $\mathrm{D}(\operatorname{LCPI}(-2))$ & -0.018099 & -0.083786 & 0.391098 & 0.018642 & -0.433708 & -0.601355 & -0.537799 & 0.331346 \\
\hline $\mathrm{D}(\operatorname{LCPI}(-3))$ & -0.001320 & -0.886773 & -0.710440 & 1.098334 & 0.667053 & -1.629340 & -0.580155 & 0.106516 \\
\hline D(LCRE(-1)) & -0.092605 & 0.477998 & 0.053273 & 0.301143 & -0.492126 & -0.175002 & -1.448020 & -0.409165 \\
\hline $\mathrm{D}(\operatorname{LCRE}(-2))$ & -0.012304 & 0.282948 & 0.491179 & -1.288482 & -0.222256 & -0.052726 & 0.459496 & -0.362025 \\
\hline D(LCRE(-3)) & -0.026444 & 0.139168 & 0.268720 & -0.512455 & -0.085998 & -0.188474 & 0.496037 & -0.183945 \\
\hline D(LVN-INDEX(-1)) & -0.015788 & 0.008458 & -0.073603 & 0.564625 & 0.016360 & -0.105510 & -0.185925 & -0.052596 \\
\hline D(LVN-INDEX(-2)) & -0.000639 & 0.044819 & -0.020601 & -0.122541 & -0.013164 & 0.100247 & 0.203289 & -0.090111 \\
\hline D(LVN-INDEX(-3)) & 0.006160 & -0.041829 & 0.046723 & 0.527374 & 0.053428 & -0.033978 & -0.015744 & 0.010915 \\
\hline $\mathrm{D}(\operatorname{LER}(-1))$ & -0.066048 & -0.440771 & -0.524018 & -1.374162 & 0.488294 & -1.165890 & -5.379066 & 0.041412 \\
\hline $\mathrm{D}(\operatorname{LER}(-2))$ & -0.035893 & 0.177878 & -0.219224 & 1.967202 & -0.456871 & -0.927016 & -4.633181 & 0.394944 \\
\hline $\mathrm{D}(\operatorname{LER}(-3))$ & -0.018983 & -0.476202 & -0.317125 & 1.464492 & 0.376213 & -0.337143 & -2.440198 & -0.168993 \\
\hline $\mathrm{D}(\operatorname{LILR}(-1))$ & -0.014985 & -0.144109 & -0.058419 & -0.184041 & 0.113018 & -0.665483 & -1.151150 & 0.162340 \\
\hline $\mathrm{D}(\operatorname{LILR}(-2))$ & -0.027054 & 0.027180 & -0.140780 & -0.230982 & -0.050959 & -0.324295 & -1.127837 & 0.110609 \\
\hline $\mathrm{D}(\operatorname{LILR}(-3))$ & -0.027981 & 0.035757 & 0.081867 & -0.256404 & -0.044635 & -0.050939 & -0.851518 & 0.081081 \\
\hline D(LISBV(-1)) & 0.013444 & 0.067473 & -0.149243 & 0.402275 & -0.007916 & 0.494120 & 0.704277 & -0.057856 \\
\hline D(LISBV(-2)) & 0.040498 & -0.108710 & 0.040928 & 0.442433 & 0.123117 & 0.207477 & 0.453600 & 0.005499 \\
\hline D(LISBV(-3)) & 0.018972 & -0.042147 & -0.144239 & 0.093211 & 0.094887 & -0.089788 & 0.648630 & -0.086337 \\
\hline $\mathrm{D}(\operatorname{LM} 2(-1))$ & 0.020328 & -0.947265 & -1.287568 & -0.949496 & 1.051011 & -0.665217 & -0.339032 & -0.043282 \\
\hline $\mathrm{D}(\mathrm{LM} 2(-2))$ & 0.004070 & -0.712887 & -0.442633 & 1.691068 & 0.668139 & -0.650545 & -2.324616 & 0.518561 \\
\hline $\mathrm{D}(\operatorname{LM} 2(-3))$ & -0.055935 & -0.637710 & -1.027294 & 1.734888 & 0.749599 & -0.794801 & -2.299520 & 0.017187 \\
\hline $\mathrm{C}$ & -0.066723 & -7.703736 & 10.11854 & 11.23571 & 4.737863 & 4.715758 & -7.303345 & 8.672521 \\
\hline LIFED & 0.001264 & -0.003808 & -0.007775 & 0.084816 & 0.004829 & 0.009298 & -0.038357 & 0.002539 \\
\hline LPW & 0.024994 & 1.644727 & -2.114125 & -2.395520 & -1.012583 & -0.954980 & 1.582943 & -1.813478 \\
\hline quared & 0.790143 & 0.932803 & 0.939131 & 0.906442 & 0.831969 & 0.959743 & 0.948850 & 0.860538 \\
\hline ddj. R-squared & 0.480354 & 0.833608 & 0.849276 & 0.768332 & 0.583923 & 0.900316 & 0.873344 & 0.654665 \\
\hline
\end{tabular}

VECM model results show the relationship between the variables in the model. From the VECM model results, it is possible to determine the impact of the policy interest rate shock (ISBV) and money supply (M2) on the average lending interest rate in VND (ILR) and the impact of ILR on other endogenous variables (through the reaction functions). At the same time, evaluate the importance of the different shocks when explaining the variability of the two final target variables of monetary policy as inflation and growth (through variance decomposition), which are shown specifically in the next section.

\subsubsection{Reaction functions}

From the results of estimating the VECM model, we consider the result of the reaction function of the average lending interest rate in the market in the next 10 quarters with assuming policy interest rate (ISBV) and money supply (M2) increased by $1 \%$ in the first quarter. The result is shown in Fig. 5 as follows. 

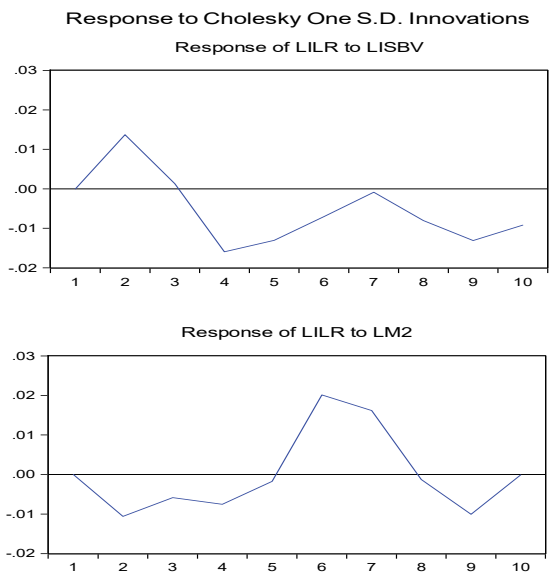

Source: Result of the model

Fig. 5. The impact of policy interest rate shock and money supply on the average lending rate in VND in the market

Looking at Fig. 5, it can be seen that when the policy interest rate (ISBV) increased by $1 \%$ in the first quarter, the average lending interest rate in VND increased in the first two quarters followed by dropping sharply in the next two quarters, then increase in 3 quarter to return to the original interest rate before falling again. When money supply (M2) increased by $1 \%$ in the first quarter, the average lending interest rate in VND decreased in the first quarter before a slight increase in the first three quarters but was still lower than the original. Which is consistent with the theory and also explains when policy interest rate (ISBV) increases in the first quarter only leading to an increasing average lending interest rate in VND in the first two quarters then dramatic dropping. Up to now, the State Bank of Vietnam is still operating monetary policy by monetary amount, so it can be seen that the impact of an increase in money supply, implementing the extensive monetary policy will affect the average lending interest rate in VND. The results of the reaction function also show that the average lending interest rate in VND increases from the 5th quarter before drop sharply in the following quarters and slightly grows up to the initial interest rate in the 10th quarter.


Source: Result of the model

Fig. 6. Impact of average loan interest rate shock on endogenous variables GDP, CPI, ER, VN-INDEX, CRE

From the estimation results of the VECM model, considering the reaction function of endogenous variables GDP, CPI, ER, CRE, VN-INDEX from the fluctuation of the average loan interest rate in VND with the assumption that this interest rate increased by $1 \%$ in the first quarter. The results are shown in Fig. 6 as follows:

The increasing average loan interest rate in VND make GDP dropping sharply in the 5 quarters before an increase in the 6th quarter and falling in the 7th quarter, followed by a slight rising in the 8th quarter, a decrease in the 9th quarter and growing up in the 10th quarter but still below the initial level in the first quarter. This shows that an increase in lending interest rates leads to rising in the production and business costs of enterprises, making difficult for production, and reducing the output of the economy. The average lending interest rate in VND increased that make CPI increased sharply in the first two quarters and decreased slightly in the 3rd quarter before going up dramatically in the 4th quarter. From the 5th to the 7th quarter, the CPI index dropped strongly followed by a rising in the 8th quarter and falling in the remaining quarters. The average lending interest 
rate in VND increased, credit to the economy decreased in the first three quarters before rising in the fourth quarter and then reverse continuously. In terms of trends, when interest rates increase, credit to the economy will decrease, this is in line with theory. The average lending interest rate in VND increased, VN-INDEX climbed slightly in the first quarter and plummeted in the next 3 quarters, this is appropriate because an increase in interest rate, the investors tend to deposit money in banks rather than investing in the stock market. From the 5th quarter, the VN-INDEX reversed and increased in the remaining quarters. This can be explained by the fluctuations of interest rates with GDP and CPI. From the 5th quarter the CPI drop and the GDP reverse in the upward trend. This shows that the growth of the economy drags on rising in the stock market. When the average lending interest rate in VND increased, the bilateral real exchange rate (ER) decreased in the first four quarters, combined with the increase in CPI as analyzed above, which made the bilateral exchange rate sharply decline. This will attract foreign investors leading to increased foreign investment into the country. From the 5th quarter, ER reversed and increased sharply again in 3 quarters and then went down in the next 2 quarters before slightly increasing in the last quarter. This can be considered reasonable as considering the fluctuations between interest rates and Vietnam's CPI, with the rising in average lending interest rate, ER and CPI have opposite reactions.

\subsubsection{Decomposition of variance}

In addition to analyzing the reaction function, variance decomposition can be used to assess the importance of different shocks when explaining the variability of the last two target variables of interest rate policy as inflation and growth. Results of decomposition of variance at table 9 show:

\section{Table 9}

Decomposition of variance

Variance Decomposition of LCPI:

\begin{tabular}{|c|c|c|c|c|c|c|c|c|c|}
\hline Period & S.E. & LGDP & LCPI & LCRE & LVN-INDEX & LER & LILR & LISBV & LM2 \\
\hline 1 & 0.009084 & 0.041452 & 99.95855 & 0.000000 & 0.000000 & 0.000000 & 0.000000 & 0.000000 & 0.000000 \\
\hline 2 & 0.013089 & 0.758330 & 83.72644 & 2.259088 & 3.142274 & 2.530492 & 3.043496 & 1.527125 & 3.012753 \\
\hline 3 & 0.015752 & 7.403318 & 64.19484 & 1.698927 & 5.253266 & 5.343790 & 3.907573 & 6.810190 & 5.388096 \\
\hline 4 & 0.017550 & 7.082764 & 51.71649 & 1.377759 & 5.584232 & 7.163620 & 15.89574 & 6.831039 & 4.348353 \\
\hline 5 & 0.018583 & 7.276100 & 48.50787 & 1.966568 & 5.285067 & 6.823082 & 15.02898 & 8.188162 & 6.924178 \\
\hline 6 & 0.020647 & 7.068218 & 43.25701 & 2.463828 & 8.608640 & 6.895215 & 12.36917 & 7.535022 & 11.80290 \\
\hline 7 & 0.022175 & 7.353920 & 38.32475 & 2.889415 & 15.12435 & 6.293679 & 10.72253 & 8.266592 & 11.02476 \\
\hline 8 & 0.023130 & 6.919050 & 35.23618 & 3.691673 & 16.17211 & 7.136021 & 11.96071 & 8.710367 & 10.17389 \\
\hline 9 & 0.023672 & 6.822886 & 33.68814 & 4.291361 & 17.17422 & 7.228124 & 11.96701 & 9.110578 & 9.717681 \\
\hline 10 & 0.024899 & 8.143873 & 31.13644 & 4.247706 & 19.69659 & 7.368412 & 10.86810 & 8.426546 & 10.11234 \\
\hline \multicolumn{10}{|c|}{ Variance Decomposition of LGDP: } \\
\hline Period & S.E. & LGDP & LCPI & LCRE & LVN-INDEX & LER & LILR & LISBV & LM2 \\
\hline 1 & 0.003908 & 100.0000 & 0.000000 & 0.000000 & 0.000000 & 0.000000 & 0.000000 & 0.000000 & 0.000000 \\
\hline 2 & 0.004148 & 90.19690 & 7.188268 & 0.030850 & 1.217113 & 0.156222 & 0.923225 & 0.219034 & 0.068387 \\
\hline 3 & 0.004536 & 75.44822 & 13.91362 & 1.790180 & 1.318334 & 4.330856 & 1.868808 & 0.984037 & 0.345948 \\
\hline 4 & 0.004967 & 72.12958 & 12.64942 & 1.749351 & 1.500281 & 4.784338 & 2.756662 & 1.579299 & 2.851071 \\
\hline 5 & 0.005867 & 71.62411 & 12.39930 & 3.257998 & 1.456107 & 3.628701 & 3.446496 & 1.877781 & 2.309502 \\
\hline 6 & 0.006459 & 66.27528 & 19.51807 & 2.888462 & 1.268510 & 3.302878 & 2.932239 & 1.890350 & 1.924212 \\
\hline 7 & 0.006916 & 58.91294 & 22.45472 & 3.709567 & 1.559914 & 5.511668 & 4.176953 & 1.649944 & 2.024291 \\
\hline 8 & 0.007152 & 60.02359 & 21.43996 & 3.472598 & 1.462429 & 5.262938 & 4.787756 & 1.549351 & 2.001368 \\
\hline 9 & 0.007923 & 62.07905 & 18.37546 & 3.712549 & 1.400235 & 4.380886 & 6.730227 & 1.475265 & 1.846329 \\
\hline 10 & 0.008189 & 61.36379 & 19.63106 & 3.620747 & 1.476879 & 4.151335 & 6.347322 & 1.560361 & 1.848507 \\
\hline
\end{tabular}

Cholesky Ordering: LGDP LCPI LCRE LVN-INDEX LER LILR LISBV LM2

Source: Result of the model

The persistent nature of inflation explains most of the fluctuation in inflation in the first quarter. In the second quarter, the average lending interest rate in VND (ILR), money supply (M2) and VN-INDEX are three factors explaining over 3\% of the variation of CPI. From the $3^{\text {rd }}$ to the $5^{\text {th }}$ quarter, the ILR was the second factor explaining the fluctuation of CPI after the CPI itself and also from the fourth quarter onwards, ILR is the factor that explains over $10 \%$ of the variation of CPI. Besides, the two variables M2 and ISBV represent the monetary policy from the third quarter onwards explain over $10 \%$ of the variation of CPI, in some quarters, that 2 variables can explain nearly $20 \%$ of the fluctuation of CPI. In the later quarters, The VN-INDEX explains more and more of the fluctuations of the CPI, from the 7th quarter onwards VN-INDEX explains over $15 \%$ of the variation in CPI. Especially, in the 10th quarter, VN-INDEX explains nearly $20 \%$ of the variation of CPI. It can be seen that the fluctuation of GDP is almost explained by itself factor in all quarters. Next is the CPI factor from the 3rd quarter that explains over $10 \%$ of the variation in GDP, especially from the 6 th quarter, CPI can explain approximately $20 \%$ of the variation in GDP. The real bilateral exchange rate ER is a second factor that explains the variability of GDP after CPI, it can see a small open 
economy like Vietnam, the exchange rate is an important factor affecting economic growth. The average lending interest rate in VND explains more and more of the fluctuation of GDP, on average ILR explains nearly $5 \%$ meanwhile the remaining factors explain about $5 \%$ of the variation of GDP

\section{Some exchanges and discussions}

The research team used the VECM model to assess the impact of interest rate channel in the monetary transmission mechanism in Vietnam. Quarterly data from the first quarter of 2005 to the fourth quarter of 2019 has been used for analysis. Granger test, co-integration test, reaction function, variance decomposition have shown that there was a certain impact of interest rate channel in the monetary transmission mechanism in Vietnam. The result of the reaction function has shown that the rising in refinancing interest rate only makes the average lending interest rate in VND increase in the first two quarters followed by a decrease in the remaining quarters. Meanwhile, the rising in money supply can make the average lending interest rate in VND decreasing in 5 quarters before growing up in the next 2 nd quarters then falling in the remaining quarters. The increase in money supply has a clear impact on interest rates is entirely understandable, because, at present, the State Bank of Vietnam still manages monetary policy based on the monetary amount, not yet converted to operating by interest rates. The results of the variance decomposition have shown that the interest rate channel is one of the important channels to transmit the impact of monetary policy on inflation in Vietnam. From the fourth and fifth quarters, interest rate channel explains over 15\%, the subsequent quarters also explain over $10 \%$ of the variation of the CPI. Besides, the model has pointed out that the exchange rate and interest rates are the channels that transmit monetary policy more strongly than credit and financial asset price channels to economic growth in Vietnam. Model results have also shown that interest rates are operated base on inflation movements in Vietnam. This can be explained in two stages: From 2005 to 2012, monetary policy in general and interest rate policy, in particular, proved to be awkward and passive especially in the period 2008 - 2012. During this period, Vietnam faced high inflation and interest rates were also high, even there were periods of interest rate racing. Interest rates were high to limit aggregate demand and curb inflation, but the results have shown that lending rates increase, inflation also increases, because the interest rate policy in this period is only adaptive and lack of initiative. From 2013 to 2019, the government has operated monetary policy and interest rate policy more smoothly and proactively intending to stabilize macroeconomy. Low-interest rates provided reasonable support for business and inflation being control stable were good signals in management of interest rates as well as monetary policy. Besides, based on CPI, the model results have also confirmed that in Vietnam, past inflation plays an important role in determining current inflation; The variability of GDP is almost explained by itself, followed by an inflation factor. This result implies that to combat inflation, the Government and the State Bank of Vietnam should first keep the inflation at a low rate for at least one quarter, thereby gaining public confidence about an environment in which prices are controlled and reduce expectations about future inflation. This also means that the Government and the State Bank of Vietnam need to persevere in the goal of controlling inflation thereby contributing to macroeconomic stability and supporting reasonable growth.

\section{References}

Hoang, T., \& Thi, V. (2020). The impact of macroeconomic factors on the inflation in Vietnam. Management Science Letters, 10(2), 333-342.

Hoang, T., Thi, V., \& Minh, H. (2020). The impact of exchange rate on inflation and economic growth in Vietnam. Management Science Letters, 10(5), 1051-1060.

Hung, L. V., \& Pfau, W. D. (2009). VAR analysis of the monetary transmission mechanism in Vietnam. Applied Econometrics and International Development, 9(1), 165-179.

Keynes, J.M. (1936), General Theory of Employment, Interest, and Currency, Published: Macmillan Cambridge University Press, for Royal Economic Society in 1936.

Nguyen, T. H., \& Nguyen, D.T. (2010), Macro Factors Influencing Vietnam's Inflation Period 2000-2010: Evidence and Discussion, Hanoi University of Economics - Vietnam National University.

Mankiw, N. G. (2010). Macroeconomics. 7th Edition, Worth Publishers.

Mishkin, F.S. (2010), The economics of money, banking and financial markets, 10th Edition by Frederic S. Mishkin

State Bank of Vietnam, Annual Report, https:/www.sbv.gov.vn/webcenter/portal/en/home/rm/public/nreport

Vietnamese Index (2020), Market statistics, https://www.stockbiz.vn/IndicesStats.aspx [Accessed: 12/01/2020].

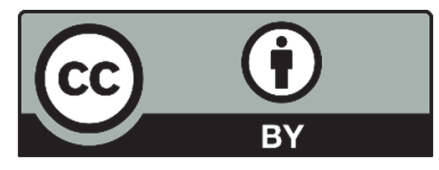

(C) 2020 by the authors; licensee Growing Science, Canada. This is an open access article distributed under the terms and conditions of the Creative Commons Attribution (CC-BY) license (http://creativecommons.org/licenses/by/4.0/). 